\title{
Editorial
}

\section{One of the Highest World Privileges ${ }^{\star}$}

\author{
levgen I. Fesenko* \\ Department of Oral and Maxillofacial Surgery, Private Higher Educational Establishment "Kyiv Medical University", Kyiv, Ukraine \\ (PhD, Assis Prof)
}

"Success is the result of perfection, hard work, learning from failure, loyalty and persistence"

\author{
-Colin Powell, \\ American statesman, \\ four-star general in U.S. Army
} \section{$<$ UF Health Jacksonville}

Dr. Rui Fernandes is now one of only three oral and maxillofacial surgeons in the United States to have been inducted into one of the world's oldest surgical organizations.

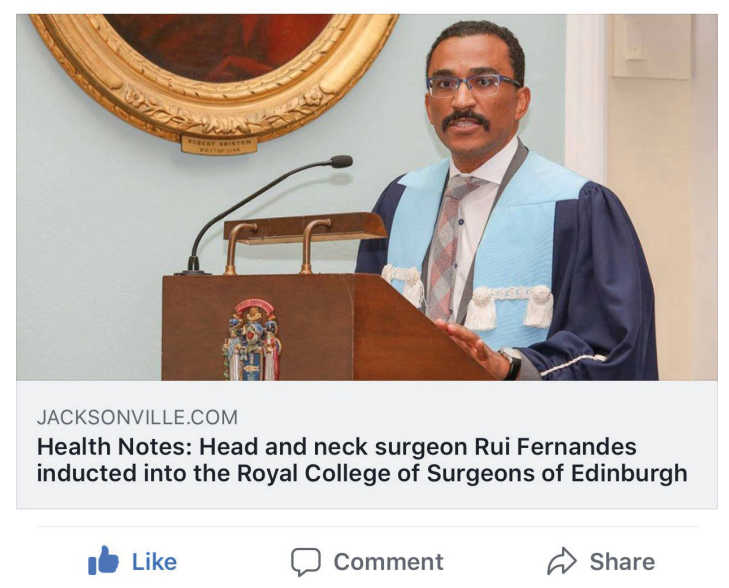

FIGURE 1. Cropped screenshot from a facebook page UF Health Jacksonville. Professor Rui P. Fernandes addresses new fellows during the induction ceremony in Edinburgh, Scotland [2].

Royal College of Surgeons of Edinburgh (RCSEd) is one of the oldest surgical corporations (professional oragization) in the world and traces its origins to 1505 [1]. The ad hominem fellow distinction is the most prestigious designation a surgeon can receive from the college. Of the more than 10,000 U.S. surgeons in his specialty, Rui P. Fernandes, MD, DMD, is just the third to be inducted as one (Fig 1) [2].

\footnotetext{
* This manuscript has not been presented

* Corresponding author. Department of Oral \& Maxillofacial Surgery, PHEE "Kyiv Medical University", 9 Lva Tolstogo Street, Kyiv 01004, Ukraine. Tel.: +38 (063) 2931813.

E-mail address: i.i.fesenko@dtjournal.org (levgen I. Fesenko)

http://dx.doi.org/10.23999/j.dtomp.2019.3.2
}

\author{
ABOUT ARTICLE \\ Article history: \\ Paper received 25 August 2018 \\ Accepted 05 September 2018 \\ Available online 30 September 2018
}

Consulting Editor of the highly prestigious Journal Oral and Maxillofacial Surgery Clinics of North America. Textbooks: Local \& Regional Flaps in Head \& Neck Reconstruction: A Practical Approach (Fernandes) published in 2014; Oral, Head \& Neck Oncology \& Reconstructive Surgery (Bell, Fernandes, Andersen) published in 2017. Co-author in the cutting-edge articles: Outcomes of total or near-total lip reconstruction with microvascular tissue transfer; Margin analysis: sarcoma of the head and neck; The cervicofacial flap in cheek reconstruction: a guide for flap design; Alternative approach in mandibular reconstruction for benign disease [3-6]. The list goes on. He don't stop to relax. He continue to do that again, and again, and again... To move a surgery forward.

\section{References}

1. Royal College of Surgeons of Edinburgh [document on the internet]; Available from: https://en.wikipedia.org/wiki/ Royal_College_of_Surgeons_of_Edinburgh.

2. Health Notes: head and neck surgeon Fernandes inducted into the Royal College of Surgeons of Edinburgh [document on the internet]; 2018 January 31 [cited 2018 Sep 03]. Available from: https://www.facebook.com/UFHealthJax/.

3. Fernandes R, Clemow J. Outcomes of total or near-total lip reconstruction with microvascular tissue transfer. $J$ Oral Maxillofac Surg 2012;70(12):2899-906. https://doi. org/10.1016/j.joms.2012.02.035.

4. Makary RF, Gopinath A, Markiewicz MR, Fernandes R. Margin analysis: sarcoma of the head and neck. Oral Maxillofac Surg Clin North Am 2017;29(3):355-66. https:// doi.org/10.1016/j.coms.2017.04.002.

5. Al Shetawi AH, Quimby A, Fernandes R. The cervicofacial flap in cheek reconstruction: a guide for flap design. J Oral Maxillofac Surg 2017;75(12):2708.e1-2708.e6. https://doi. org/10.1016/j.joms.2017.08.006.

6. Al Shetawi AH, Fernandes R. Alternative approach in mandibular reconstruction for benign disease. J Oral Maxillofac Surg 2018;76(1):229.e1-229.e9. https://doi. org/10.1016/j.joms.2017.06.041. 